\title{
Short communication: Comparison of growth kinetics at different temperatures of Streptococcus macedonicus and Streptococcus thermophilus strains of dairy origin
}

\author{
Armin Tarrah, ${ }^{*}$ Valentina Noal, ${ }^{*}$ Laura Treu, $†$ Sabrina Giaretta, ${ }^{*}$ Vinícius da Silva Duarte, $\ddagger$ Viviana Corich, ${ }^{* 1}$ \\ and Alessio Giacomini* \\ *Department of Agronomy Food Natural resources Animals and Environment (DAFNAE) Agripolis, University of Padova, Viale dell'Università 16, \\ 35020 Legnaro (PD), Italy \\ †Department of Environmental Engineering, Technical University of Denmark, Miljoevej, Building 115, DK-2800 Kgs, Lyngby, Denmark \\ †Department of Microbiology, Universidade Federal de Viçosa, Viçosa-MG, Brazil 36570-000
}

\section{ABSTRACT}

Within the genus Streptococcus, S. thermophilus and S. macedonicus are the 2 known species related to foods. Streptococci are widely used as starter cultures to rapidly lower milk $\mathrm{pH}$. As $S$. macedonicus has been introduced quite recently, much less information is available on its technological potential. Because temperature is an important factor in fermented food production, we compared the growth kinetics over 24 $\mathrm{h}$ of 8 S. thermophilus and 7 S. macedonicus strains isolated from various dairy environments in Italy, at 4 temperatures, $30^{\circ} \mathrm{C}, 34^{\circ} \mathrm{C}, 37^{\circ} \mathrm{C}$ and $42^{\circ} \mathrm{C}$. We used the Gompertz model to estimate the 3 main growth parameters; namely, lag phase duration $(\lambda)$, maximum growth rate $\left(\mu_{\max }\right)$, and maximum cell number at the stationary phase $\left(\mathrm{N}_{\max }\right)$. Our results showed significant differences in average growth kinetics between the 2 species. Among the strains tested, $37^{\circ} \mathrm{C}$ appeared to be the optimal temperature for the growth of both species, particularly for S. macedonicus strains, which showed mean shorter lag phases and higher cell numbers compared with $S$. thermophilus. Overall, the growth curves of $S$. macedonicus strains were more similar to each other whereas $S$. thermophilus strains grew very differently. These results help to better define and compare technological characteristics of the 2 species, in view of the potential use of $S$. macedonicus in place of $S$. thermophilus in selected technological applications.

Key words: starter culture, growth kinetics, Gompertz model

Received March 12, 2018.

Accepted May 14, 2018.

${ }^{1}$ Corresponding author: viviana.corich@unipd.it

\section{Short Communication}

Within the genus Streptococcus, S. thermophilus and S. macedonicus are 2 species related to foods. Although the first is very well known and used in production of a large number of fermented products, S. macedonicus is a relatively new species (Tsakalidou et al., 1998) isolated from dairy products. Streptococcus thermophilus is widely used in starter cultures with the aim of growing rapidly and decreasing the $\mathrm{pH}$, because changes in $\mathrm{pH}$ induce modifications in the bacterial population composition (Bovo et al., 2012; Maragkoudakis et al., 2013). Although much less is known about S. macedonicus, several studies have been devoted to its characterization and to the definition of several features relevant for food production; for example, synthesis of exopolysaccharides, bacteriocin production, and response to acid stress (De Vuyst and Tsakalidou, 2008). In addition, some strains have been used for the production of trial cheeses (Settanni et al., 2011, 2013; Guarcello et al., 2016). Because of the presence of such potential technological features, better knowledge of this new species would be useful.

In the present study, we analyzed growth of $8 S$. thermophilus and 7 S. macedonicus strains of dairy origin isolated in northeast Italy (Table 1) at different temperatures to assess and compare their growth kinetics. Strains were stored at $-80^{\circ} \mathrm{C}$ in brain-heart infusion broth (Oxoid, Basingstoke, UK) plus 25\% (vol/vol) glycerol and were subcultured twice before use in 10 $\mathrm{mL}$ of M17 medium (Oxoid) containing lactose $(0.5 \%)$ in $15-\mathrm{mL}$ tubes. Cultures were grown at $37^{\circ} \mathrm{C}$ for $24 \mathrm{~h}$. Growth studies were done in 96-well microtiter plates (SIAL0596, Sigma St. Louis, MO) with a microtiter plate incubator reader (Spark 10M, Tecan GmbH, Grödig, Austria). Overnight cultures $(10 \mathrm{~mL})$ were centrifuged at $10,000 \times g$ for $10 \mathrm{~min}$. Pellets were then washed twice with $5 \mathrm{~mL}$ of PBS and resuspended in 5 $\mathrm{mL}$ of sterile PBS. 
Table 1. Bacterial strains of Streptococcus thermophilus and Streptococcus macedonicus isolated from northeast Italy and used in this study

\begin{tabular}{|c|c|c|c|}
\hline Strain & Isolation matrix & Geographical origin & Source or reference \\
\hline S. thermophilus TH1435 & Goat raw milk & Friuli Venezia Giulia & Treu et al., 2014a \\
\hline S. thermophilus TH1477 & Cow raw milk & Veneto & Treu et al., 2014b \\
\hline S. thermophilus TH982 & Buffalo mozzarella curd & Campania & Treu et al., 2014b \\
\hline S. thermophilus TH985 & Buffalo mozzarella whey & Campania & Treu et al., 2014b \\
\hline S. thermophilus M17PTZA496 & Fontina cheese (cow) & Valle d'Aosta & Treu et al., 2014c \\
\hline S. macedonicus $19 \mathrm{AS}$ & Natural milk culture for Asiago cheese (cow) & Veneto & Treu et al., 2017 \\
\hline S. macedonicus $62 \mathrm{AS}$ & Natural milk culture for Asiago cheese (cow) & Veneto & Lombardi et al., 2004 \\
\hline S. macedonicus $27 \mathrm{MV}$ & Monte Veronese cheese (cow) & Veneto & Treu et al., 2017 \\
\hline S. macedonicus 203MA & Malga cow cheese & Veneto & Veneto Agricoltura $^{1}$ \\
\hline S. macedonicus $211 \mathrm{MA}$ & Malga cow cheese & Veneto & Treu et al., 2017 \\
\hline S. macedonicus $33 \mathrm{MO}$ & Curd of Morlacco cheese (cow) & Veneto & Vendramin et al., 2014 \\
\hline
\end{tabular}

${ }^{1}$ Veneto Agricoltura, Istituto per la Qualità e le Tecnologie Agroalimentari, Thiene, Italy.

Cell concentration was standardized to $10^{6}$ cells $/ \mathrm{mL}$ in M17 medium plus $0.5 \%$ lactose at $\mathrm{pH}$ 7.0, aliquoted into microtiter wells $(200 \mu \mathrm{L}$ per well), and incubated at 1 of 4 selected temperatures: $30^{\circ} \mathrm{C}, 34^{\circ} \mathrm{C}, 37^{\circ} \mathrm{C}$, or $42^{\circ} \mathrm{C}$ for $24 \mathrm{~h}$ inside the plate reader. Growth was measured by automatically reading the absorbance (optical density at $600 \mathrm{~nm}$ ) every $30 \mathrm{~min}$. All experiments were done using 3 biological and 4 technical replicates. Blank and negative controls were included in all experiments. The Gompertz model (Zwietering et al., 1990) was applied to estimate the main growth parameters; namely, lag phase duration $(\boldsymbol{\lambda})$, maximum growth rate $\left(\boldsymbol{\mu}_{\max }\right)$, and maximum cell number at the stationary phase $\left(\mathbf{N}_{\max }\right)$.

SigmaPlot software version 12.0 (Systat Software, San Jose, CA) was used for statistical analysis. The ShapiroWilk test was used to evaluate normal distribution of data. After the normality test, data were analyzed for statistical significance using ANOVA followed using the Tukey test. Data with a non-normal distribution were analyzed by nonparametric test (Dunn method).

Growth curves for S. thermophilus and S. macedonicus obtained at different temperatures are reported in Figure 1, and growth parameters $\left(\lambda, \mu_{\max }\right.$, and $\left.\mathrm{N}_{\max }\right)$, calculated by applying the Gompertz model, are reported in Table 2 . These 3 parameters concisely describe population growth kinetics under specific environmental conditions and are therefore useful for evaluating strain performance in view of their technological use. In general, low $\lambda$ values indicate that a strain can rapidly begin multiplying, thus hindering the development of the indigenous microbiota. High $\mu_{\max }$ values indicate that bacteria are colonizing the substrate rapidly and efficiently, and high $\mathrm{N}_{\max }$ values indicate that a high number of bacteria are present at the end of the growth process, which is a valuable feature of a fermented food.
Although S. thermophilus strains can growth at temperatures ranging from about $25^{\circ} \mathrm{C}$ to $50^{\circ} \mathrm{C}$ (Vaningelgem et al., 2004), we chose 4 temperatures used for most technological applications, because it is well established that temperature plays a role in the production of substances; for example, benzoic acid (Han et al., 2016) or exopolysaccharide (Li et al., 2016), and affects the technological characteristics of fermented food products (Nor-Khaizura et al., 2014; Westerik et al., 2016). Regarding S. macedonicus, only 2 strains have been tested so far for growth at different temperatures. Streptococcus macedonicus ACA-198 (Poirazi et al., 2007) was studied for bacteriocin production, which was the highest at $40^{\circ} \mathrm{C}$; and strain $\mathrm{LC} 743$ (Cho et al., 2010), incubated at $34^{\circ} \mathrm{C}, 37^{\circ} \mathrm{C}$ and $40^{\circ} \mathrm{C}$, showed the highest growth rate at $40^{\circ} \mathrm{C}$. Therefore, our results for the strains used in this work add new information concerning this species.

Overall, from the growth curves reported in Figure 1, it can be seen that $S$. macedonicus strains showed less variability, particularly at $30^{\circ} \mathrm{C}, 34^{\circ} \mathrm{C}$, and $42^{\circ} \mathrm{C}$, with respect to $S$. thermophilus. Clearly, higher temperatures resulted in better growth rates, but no significant $(P$ $<0.05)$ further increase was observed in either species at $42^{\circ} \mathrm{C}\left(1.55 \pm 0.25 \mathrm{~h}^{-1}\right.$ at $37^{\circ} \mathrm{C}$ vs. $1.79 \pm 0.62 \mathrm{~h}^{-1}$ at $42^{\circ} \mathrm{C}$ for $S$. macedonicus; $1.46 \pm 0.31 \mathrm{~h}^{-1}$ at $37^{\circ} \mathrm{C}$ vs. $1.34 \pm 0.35 \mathrm{~h}^{-1}$ at $42^{\circ} \mathrm{C}$ for $S$. thermophilus; Table 2 ), indicating that this temperature is beyond the optimum. At $30^{\circ} \mathrm{C}$, all S. macedonicus strains showed a significantly $(P<0.05)$ shorter lag phase and reached a significantly $(P<0.05)$ higher $\mathrm{N}_{\max }$ compared with $S$. thermophilus. Moreover, the shapes of the S. thermophilus growth curves highlighted marked differences among strains, in contrast to strains of $S$. macedonicus. Although $30^{\circ} \mathrm{C}$ appears nonoptimal for $S$. thermophilus growth, it is the best choice for the development 
Table 2. Growth parameters of strains of Streptococcus macedonicus and Streptococcus thermophilus estimated by the Gompertz model ${ }^{1}$

\begin{tabular}{|c|c|c|c|c|c|c|c|c|c|c|c|c|}
\hline $\begin{array}{l}\text { Species and } \\
\text { strain }\end{array}$ & \multicolumn{3}{|c|}{$30^{\circ} \mathrm{C}$} & \multicolumn{3}{|c|}{$34^{\circ} \mathrm{C}$} & \multicolumn{3}{|c|}{$37^{\circ} \mathrm{C}$} & \multicolumn{3}{|c|}{$42^{\circ} \mathrm{C}$} \\
\hline $8 \mathrm{SP}$ & 0.03 & 0.89 & 1.01 & 0.44 & 1.26 & 1.04 & 0.20 & 1.41 & 1.04 & 0.59 & 1.93 & 1.06 \\
\hline $19 \mathrm{AS}$ & 0.10 & 0.90 & 0.80 & 0.71 & 1.10 & 0.76 & 0.05 & 1.93 & 0.95 & 0.00 & 0.58 & 0.60 \\
\hline $27 \mathrm{MV}$ & 0.94 & 1.05 & 0.83 & 1.13 & 1.24 & 0.91 & 0.24 & 1.73 & 0.96 & 0.58 & 1.73 & 0.88 \\
\hline 211MA & 0.74 & 1.12 & 1.02 & 0.62 & 1.58 & 1.04 & 1.09 & 1.41 & 1.09 & 0.66 & 2.48 & 0.99 \\
\hline Mean & 0.50 & 0.98 & 0.88 & 0.76 & 1.26 & 0.93 & 0.77 & 1.55 & 1.01 & 0.64 & 1.79 & 0.90 \\
\hline $\mathrm{SD}$ & 0.43 & 0.12 & 0.14 & 0.29 & 0.16 & 0.20 & 1.02 & 0.25 & 0.06 & 0.42 & 0.62 & 0.15 \\
\hline \multicolumn{13}{|l|}{ S. thermophilus } \\
\hline $1 \mathrm{~F} 8 \mathrm{CT}$ & 6.33 & 0.31 & 0.07 & 1.12 & 0.58 & 1.07 & 2.06 & 1.33 & 0.84 & 0.62 & 0.86 & 0.51 \\
\hline MTH17CL396 & 2.89 & 2.31 & 0.56 & 0.74 & 1.24 & 0.80 & 3.48 & 1.93 & 0.80 & 0.63 & 1.54 & 0.88 \\
\hline TH1477 & 2.16 & 0.64 & 0.70 & 0.70 & 1.00 & 0.82 & 2.30 & 1.03 & 0.90 & 0.17 & 1.28 & 0.89 \\
\hline Mean & $3.07^{*}$ & 0.89 & $0.55^{*}$ & 1.44 & 1.01 & 0.80 & $2.40^{*}$ & 1.46 & $0.85^{*}$ & 0.94 & 1.34 & $0.70^{*}$ \\
\hline $\mathrm{SD}$ & 1.46 & 0.63 & 0.24 & 1.20 & 0.25 & 0.20 & 0.54 & 0.31 & 0.06 & 0.96 & 0.35 & 0.14 \\
\hline
\end{tabular}

$\overline{{ }^{1} \lambda}=$ lag phase duration; $\mu_{\max }=$ maximum growth rate; $\mathrm{N}_{\max }=$ maximum cell number at the stationary phase $\left(\right.$ where $\mathrm{OD}_{600}=\mathrm{optical} \mathrm{density}$ at $600 \mathrm{~nm})$.

${ }^{*} P<0.05$ : statistically significant differences between species (ANOVA, Tukey's test).
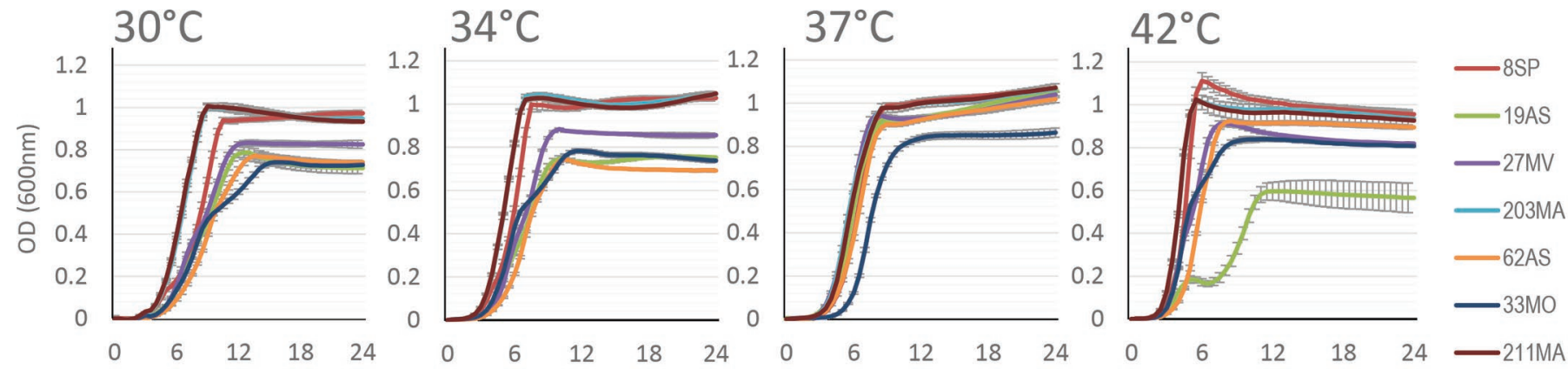

S. macedonicus
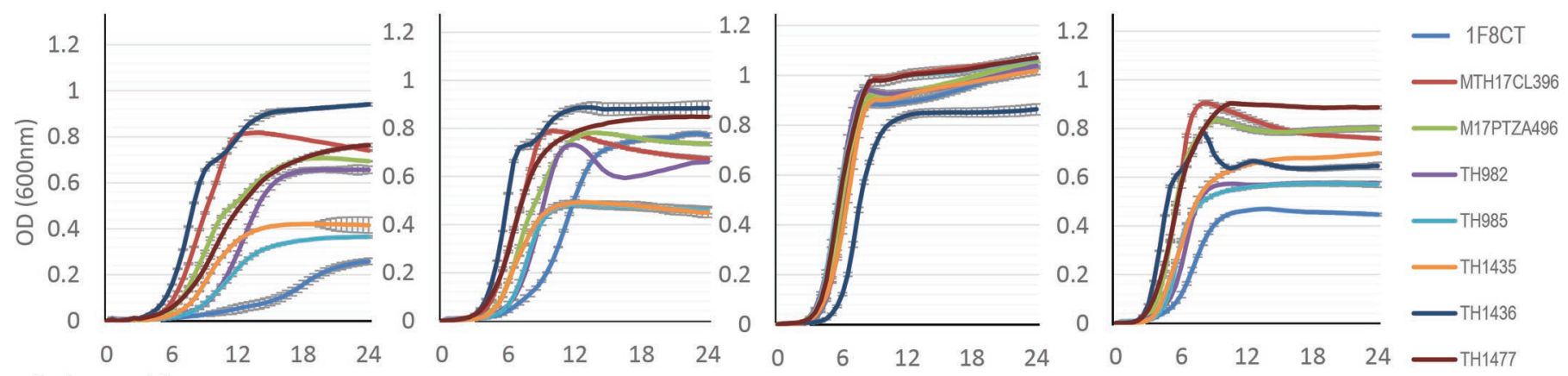

S. thermophilus

Time (h)

Figure 1. Growth curves (measured as optical density at $600 \mathrm{~nm}$ ) for strains (colored curves; strain details given in Table 1) of Streptococcus thermophilus and Streptococcus macedonicus obtained at different temperatures. Vertical bars represent SEM. Color version available online. 
of some activities, such as production of bacteriocin (Aktypis et al., 2007) or exopolysaccharides (Purwandari et al., 2007; Kanamarlapudi and Muddada, 2017). At $34^{\circ} \mathrm{C}$, mean $\mu_{\max }$ increased, as expected, in both species, and $S$. thermophilus had a shorter lag phase with respect to that determined at $30^{\circ} \mathrm{C}$. From comparison of the growth curves (Figure 1), it is evident that greater diversity existed among $S$. thermophilus strains than among $S$. macedonicus. At $37^{\circ} \mathrm{C}$, all strains had similar kinetics and reached their respective optimal growth parameters, but S. macedonicus strains showed a significantly $(P<0.05)$ shorter lag phase and higher $\mathrm{N}_{\max }$. At $42^{\circ} \mathrm{C}$, a generalized decrease in growth performance was observed for both species, indicating suboptimal growth conditions. In particular, the population levels $\left(\mathrm{N}_{\max }\right)$ obtained by $S$. thermophilus strains were significantly lower $(P<0.05)$ than those of $S$. macedonicus. Thus, $37^{\circ} \mathrm{C}$ could be considered the optimal temperature, among those tested, for all strains, whereas growth becomes strongly strain dependent at temperatures other than $37^{\circ} \mathrm{C}$.

All $S$. macedonicus strains tended to increase growth performance with increasing temperature but growth rate did not increase further from $37^{\circ} \mathrm{C}$ to $42^{\circ} \mathrm{C}$; indeed, strain $19 \mathrm{AS}$ appeared seriously impaired at $42^{\circ} \mathrm{C}$. Streptococcus thermophilus strains grew very differently from each other; for instance, TH1436 grew better at lower temperatures, whereas TH1477 and TH1435 grew better at $37^{\circ} \mathrm{C}$.

In conclusion, we report for the first time the growth kinetics and optimal temperature for S. macedonicus strains and compare kinetics with those of $S$. thermophilus under the same conditions. These data help to better define and compare technological characteristics of the 2 species, in view of the potential use of $S$. macedonicus to replace $S$. thermophilus in selected technological applications. Further studies will be needed on a greater number of $S$. macedonicus isolates to evaluate whether the relatively homogeneous behavior shown by the strains used in this work is due to their relative geographical proximity (all isolated in northeast Italy) or is an intrinsic characteristic of the species.

\section{ACKNOWLEDGMENTS}

This study was funded in part by the Ministero dell'Università e della Ricerca Scientifica (DOR).

\section{REFERENCES}

Aktypis, A., M. Tychowski, G. Kalantzopoulos, and G. Aggelis. 2007. Studies on bacteriocin (thermophilin T) production by Streptococcus thermophilus ACA-DC 0040 in batch and fed-batch fermen- tation modes. Antonie van Leeuwenhoek 92:207-220. https://doi .org/10.1007/s10482-007-9148-4.

Bovo, B., T. Nardi, F. Fontana, M. Carlot, A. Giacomini, and V. Corich. 2012. Acidification of grape marc for alcoholic beverage production: Effects on indigenous microflora and aroma profile after distillation. Int. J. Food Microbiol. 152:100-106. https://doi .org/10.1016/j.ijfoodmicro.2011.10.006.

Cho, S.-A., K.-S. Kim, J.-R. Do, S.-H. Kim, and S.-D. Lim. 2010. Physiological characteristics and immunomodulating activity of Streptococcus macedonicus LC743 isolated from raw milk. Han-gug Chugsan Sigpum Hag-hoeji 30:957-965. https://doi.org/10.5851/ kosfa.2010.30.6.957.

De Vuyst, L., and E. Tsakalidou. 2008. Streptococcus macedonicus, a multi-functional and promising species for dairy fermentations. Int. Dairy J. 18:476-485. https://doi.org/10.1016/j.idairyj.2007.10 .006 .

Guarcello, R., S. Carpino, R. Gaglio, A. Pino, T. Rapisarda, C. Caggia, G. Marino, C. L. Randazzo, L. Settanni, and M. Todaro. 2016. A large factory-scale application of selected autochthonous lactic acid bacteria for PDO Pecorino Siciliano cheese production. Food Microbiol. 59:66-75. https://doi.org/10.1016/j.fm.2016.05.011.

Han, N., S.-Y. Park, S.-Y. Kim, M.-Y. Yoo, H.-D. Paik, and S.-D. Lim. 2016. Short communication: Change of naturally occurring benzoic acid during skim milk fermentation by commercial cheese starters. J. Dairy Sci. 99:8633-8637. https://doi.org/10.3168/jds .2016-10890.

Kanamarlapudi, S. L. R. K., and S. Muddada. 2017. Characterization of exopolysaccharide produced by Streptococcus thermophilus CC30. BioMed Res. Int. 2017:4201809. https://doi.org/10.1155/ $2017 / 4201809$

Li, D., J. Li, F. Zhao, G. Wang, Q. Qin, and Y. Hao. 2016. The influence of fermentation condition on production and molecular mass of EPS produced by Streptococcus thermophilus 05-34 in milk-based medium. Food Chem. 197:367-372. https://doi.org/10 $.1016 /$ j.foodchem.2015.10.129.

Lombardi, A., M. Gatti, L. Rizzotti, S. Torriani, C. Andrighetto, and G. Giraffa. 2004. Characterization of Streptococcus macedonicus strains isolated from artisanal Italian raw milk cheeses. Int. Dairy J. 14:967-976. https://doi.org/10.1016/j.idairyj.2004.04.005.

Maragkoudakis, P. A., T. Nardi, B. Bovo, M. D'Andrea, K. S. Howell, A. Giacomini, and V. Corich. 2013. Biodiversity, dynamics and ecology of bacterial community during grape marc storage for the production of grappa. Int. J. Food Microbiol. 162:143-151. https://doi.org/10.1016/j.ijfoodmicro.2013.01.005.

Nor-Khaizura, M.-A.-R., S. H. Flint, O. J. McCarthy, J. S. Palmer, M. Golding, and A. Jaworska. 2014. Designing processing and fermentation conditions for long-life set yoghurt for made-in-transit (MIT) product. J. Food Process Eng. 37:19-26. https://doi.org/ 10.1111/jfpe. 12055 .

Poirazi, P., F. Leroy, M. D. Georgalaki, A. Aktypis, L. De Vuyst, and E. Tsakalidou. 2007. Use of artificial neural networks and a gamma-concept-based approach to model growth of and bacteriocin production by Streptococcus macedonicus ACA-DC 198 under simulated conditions of Kasseri cheese production. Appl. Environ. Microbiol. 73:768-776. https://doi.org/10.1128/AEM.01721-06.

Purwandari, U., N. P. Shah, and T. Vasiljevic. 2007. Effects of exopolysaccharide-producing strains of Streptococcus thermophilus on technological and rheological properties of set-type yoghurt. Int. Dairy J. 17:1344-1352. https://doi.org/10.1016/j.idairyj.2007.01 .018 .

Settanni, L., E. Franciosi, A. Cavazza, P. S. Cocconcelli, and E. Poznanski. 2011. Extension of Tosèla cheese shelf-life using nonstarter lactic acid bacteria. Food Microbiol. 28:883-890. https:// doi.org/10.1016/j.fm.2010.12.003

Settanni, L., R. Gaglio, R. Guarcello, N. Francesca, S. Carpino, C. Sannino, and M. Todaro. 2013. Selected lactic acid bacteria as a hurdle to the microbial spoilage of cheese: Application on a traditional raw ewes' milk cheese. Int. Dairy J. 32:126-132. https://doi .org/10.1016/j.idairyj.2013.04.010. 
Treu, L., B. de Diego-Díaz, K. Papadimitriou, E. Tsakalidou, A. Giacomini, and V. Corich. 2017. Whole-genome sequences of three Streptococcus macedonicus strains isolated from Italian cheeses in the Veneto region. Genome Announc. 5:e01358-17. https://doi .org/10.1128/genomeA.01358-17.

Treu, L., V. Vendramin, B. Bovo, S. Campanaro, V. Corich, and A. Giacomini. 2014a. Whole-genome sequences of Streptococcus thermophilus strains TH1435 and TH1436, isolated from raw goat milk. Genome Announc. 2:e01129-13. https://doi.org/10.1128/ genomeA.01129-13.

Treu, L., V. Vendramin, B. Bovo, S. Campanaro, V. Corich, and A. Giacomini. 2014b. Genome sequences of four Italian Streptococcus thermophilus strains of dairy origin. Genome Announc. 2:e0012614. https://doi.org/10.1128/genomeA.00126-14.

Treu, L., V. Vendramin, B. Bovo, S. Campanaro, V. Corich, and A. Giacomini. 2014c. Genome sequences of Streptococcus thermophilus strains MTH17CL396 and M17PTZA496 from Fontina, an Italian PDO cheese. Genome Announc. 2:e0067-14. https://doi.org/10 .1128/genomeA.00067-14.

Tsakalidou, E., E. Zoidou, B. Pot, L. Wassill, W. Ludwig, L. A. Devriese, G. Kalantzopoulos, K. H. Schleifer, and K. Kersters. 1998.
Identification of streptococci from Greek Kasseri cheese and description of Streptococcus macedonicus sp. nov. Int. J. Syst. Bacteriol. 48:519-527. https://doi.org/10.1099/00207713-48-2-519.

Vaningelgem, F., M. Zamfir, T. Adriany, and L. De Vuyst. 2004. Fermentation conditions affecting the bacterial growth and exopolysaccharide production by Streptococcus thermophilus ST 111 in milk-based medium. J. Appl. Microbiol. 97:1257-1273. https://doi .org/10.1111/j.1365-2672.2004.02418.x.

Vendramin, V., L. Treu, B. Bovo, S. Campanaro, V. Corich, and A. Giacomini. 2014. Whole-genome sequence of Streptococcus macedonicus strain 33MO, isolated from the curd of Morlacco cheese in the Veneto region (Italy). Genome Announc. 2:e00746-14. https:// doi.org/10.1128/genomeA.00746-14.

Westerik, N., A. P. Wacoo, W. Sybesma, and R. Kort. 2016. Novel production protocol for small-scale manufacture of probiotic fermented foods. J. Vis. Exp. 2016. https://doi.org/10.3791/54365.

Zwietering, M. H., I. Jongenburger, F. M. Rombouts, and K. Van't Riet. 1990. Modeling of the bacterial growth curve. Appl. Environ. Microbiol. 56:1875-1881. https://doi.org/10.1111/j.1472-765X $.2008 .02537 . \mathrm{x}$ 